JOURNAL OF SECURITY AND SUSTAINABILITY ISSUES

ISSN 2029-7017/ISSN 2029-7025 (online)

2020 Volume 9 May

http://doi.org/10.9770/jssi.2020.9.M(17)

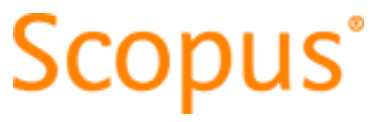

\title{
GREEN AGILITY REVOLUTION VIA INNOVATION: A CASE STUDY
}

\author{
Muhartini Salim ${ }^{1}$, Lizar Alfansi ${ }^{2}$, Muhammad Rahman Febliansa ${ }^{3}$, Marlina Widiyanti ${ }^{4}$ \\ ${ }^{1,2}$ Faculty of Economics and Business, Universitas Bengkulu, Indonesia \\ ${ }^{3}$ Faculty of Economics, University of Dehasen, Bengkulu, Indonesia \\ ${ }^{4}$ Faculty of Economics, Universitas Sriwijaya, Palembang, Indonesia \\ Email: muhartinisalimadharsyah@gmail.com (Corresponding author)
}

Received 11 October 2020; accepted 25 March 2020; published 30 May 2020

\begin{abstract}
The current study emphasized the role of market innovation on pricing, packaging, and promotion in improving marketing performance of the Apparel industry of Indonesia. Also, the mediating effect of green product market agility was examined. The data has been drawn from a sample of 309 respondents with purposive sampling. The statistical relationships between the incorporated variables are examined through Confirmatory factors analysis and Structural equation modeling approach with the application of descriptive analysis, $\mathrm{KMO}$ and Bartlett's test, rotated component matrix, convergent and discriminant validity. From the results, it is indicated in the direct effects that marketing innovation on pricing and promotion are the significant drivers of the firm's marketing performance. Whereas, no significant direct relationship between marketing innovation on packaging and marketing performance was found. In the same way, the indirect effects show that green product market agility plays a significant mediating role in the relationship between marketing innovation on price, marketing innovation on promotion, and marketing innovation on packaging and marketing performance. Moreover, various implications in terms of theory, practices, and policy development are suggested by the study for the practitioners of marketing management to assist in the achievement of effective marketing performance. Also, the study provides directions and recommendations for future researchers.
\end{abstract}

Keywords: green agility; marketing performance; marketing innovation on pricing; packaging; promotion, Indonesia

Reference to this paper should be made as follows: Salim, M., Alfansi, L., Febliansa, M.R., Widiyanti, M. 2020. Green agility revolution via innovation: a case study. Journal of Security and Sustainability Issues, 9(M), 214-228. https://doi.org/10.9770/jssi.2020.9.3(17)

JEL Codes: Q1, Q50

\section{Introduction}

In Indonesia, responsiveness towards ecological concern is increasing. Although not in fast pace, the sensitivity towards green programs is making space for itself. Green programs refer to making something, like in case of business the products and services that are beneficial to people as well as the surroundings. Awareness about this fact is growing due to alarming global warming influence and unsafe and risky living styles of people (Hailegiorgis \& Hagos, 2016; Hendrayati \& Gaffar, 2016). The purpose of these growing green programs are to make the life of people better by offering them healthy and safe products and along with that making a positive and nice impact of environment. A small portion of firms in Indonesia are using the total quality management for green products, and a relatively large portion of manufacturing firms are using green movement in fractions. However the sector of apparel in Indonesia is lacking in this concern. Being a part of green programs is a good happening for Indonesia but it needs fast pace as environmental degradations are increasing very swiftly. Green marketing, which means green or ecological programs, is the obligation of all participants in business community (Benzo, Mohsen, \& Fourali, 2017; Costanza, 2017; Dam, Le Dinh, \& Menvielle, 2019; Dewnarain, Ramkissoon, \& Mavondo, 2019; Di Fatta, Caputo, \& Dominici, 2018). The possible participants of the community are corporal experts, management, fiscal and monetary establishments, government institutes, NGOs and end users that are the customers. There are 
JOURNAL OF SECURITY AND SUSTAINABILITY ISSUES

ISSN 2029-7017/ISSN 2029-7025 (online)

2020 Volume 9 May

http://doi.org/10.9770/jssi.2020.9.M(17)

some hurdles and problems that discourage individual to buy, and manufacturer to produce green. Firms in Indonesia can use possible innovative tactics to eliminate or at least reduce such problems and difficulties. Innovation in pricing which comes in form in green pricing can help manufacturers to offer green products, for such pricing, behaviors are examined about environmental concerns initially, so the customers willingly pay extra for green products. Similarly green packaging tactic is used. Here producers offer packaging that are not only beautiful but are quite easy to transfer, reusable, recyclable able and eco-friendly. Other possible tactic that firms of Indonesia can use is innovative promotion with regards to green programs. Online, printed and television ads about green products drag attention of people, but the trick is to communicate green message effectively (Lim, 2016; Nadda, Dadwal, \& Rahimi, 2017; Nguyen, Melewar, \& Schultz, 2017). If these innovative tactics are used by firms, the attractiveness of their product increase, which increase their demand in the market. These tactics increase the agility of products in the market. Consequently the performance of a product in a market can boost. So these tactics, if applied sensibly, can lead to a competitive edge for a firm in Indonesia. This way customer will be encouraged to buy green products and if they are aware enough and understand the importance of being green, they pay extra for it eagerly. Hence a win-win situation is created where all participant are happy with no harmful effect on environment. Apparel industry is one of growing industry of Indonesia as sales increase showed in figure 1 below, so such innovative changes will simply multiply the profits.

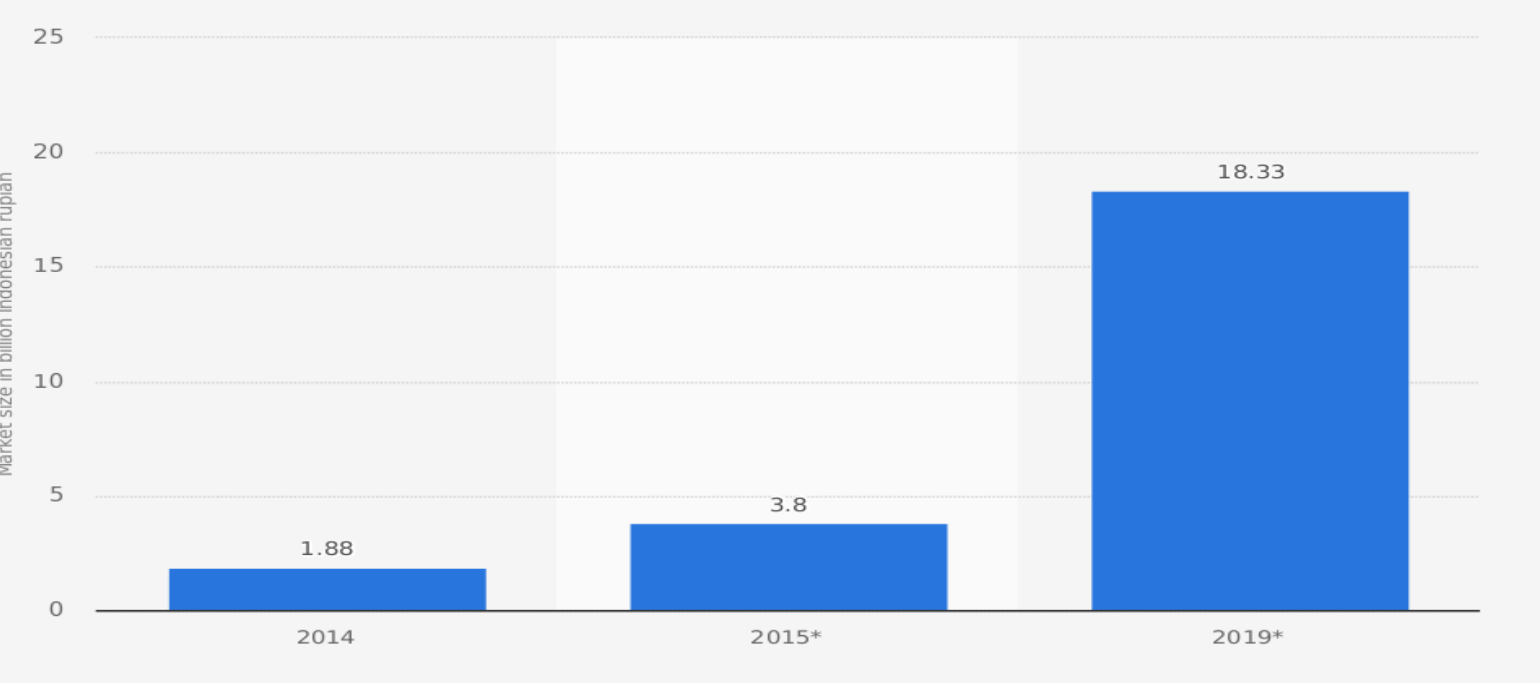

Figure 1: Apparel sales in Indonesia in 2014, 2015 and 2019 (in billion Indonesian rupiah)

The green programs are a need due to danger prevailing in environment. The waste from manufacturing, materials used in production often cause harm towards environment and when they are not properly disposed the danger increase (Atanassova \& Clark, 2015; Benzo et al., 2017; Costanza, 2017). Such harms toward earth are happening in all over the world and more specifically in developing countries. The environmental degradations in Indonesia need attention, so proper solution from all bodies effecting to the environment are required. Manufacturing firms more specifically apparel industry can play its role by adopting innovative ways. The innovations can help not only in reducing bad effects on environment but leads to high margins as well. Innovations in apparel industry of Indonesia are required to compete domestically and globally (Vătămănescu, Gazzola, Dincă, \& Pezzetti, 2017; Wang \& Kim, 2017; West, Ford, \& Ibrahim, 2015; Yaacob, Baroto, Kamarudin, \& Arifin, 2019). If these issued are addressed by courtiers it will harm the whole world's wellbeing. If companies will ignore these green innovations their profit margins will drop, and their image will be affected as other firms along the globe are adopting green ways of doing business (Haseeb et al., 2020). There is a need for this study because existing studies measure the impact of innovation on market performance but effect of green innovations on market performance is 
JOURNAL OF SECURITY AND SUSTAINABILITY ISSUES

ISSN 2029-7017/ISSN 2029-7025 (online)

2020 Volume 9 May

http://doi.org/10.9770/jssi.2020.9.M(17)

lacked. Also the apparel industry of Indonesia is not studied in this context. The mediating role of green product market agility between market innovative dimensions and market performance is not studied before.

The other sections of this study are. Section 2 which encompass theoretical background and hypothesis development. Section 3 which covers methodology and data collection. Section 4 includes analysis and results of results of data. Section 5 include conclusion.

This study has following objectives.

1. To analyze the impact of marketing innovation on pricing on marketing performance in apparel industry of Indonesia.

2. To analyze the impact of marketing innovation on packaging on marketing performance in apparel industry of Indonesia.

3. To analyze the impact of marketing innovation on promotion on marketing performance in apparel industry of Indonesia.

4. To analyze the mediating role of green product market agility (GPMA) between dimensions of innovation on marketing performance in apparel industry of Indonesia.

\section{Literature Review and Green Marketing theory}

Organizations are engaging in a variety of activities such as entrepreneurship to improve their performance (c.f., Khalid, Ahmed, Tundikbayeva \& Ahmed, 2019). The concept of marketing is also one of those new entities. The concept of green marketing was developed in 1880s. At that time this concept was not very clear, and it was not explored speedily. Initially amount of research on this concept was very small and that's why companies' interest in green marketing was limited. Their interest was expanded later when studies on green marketing expressing key novelties and modifications. After that firms started taking advantage of green marketing but this happened gradually, stories of firms like Body Shop and McDonalds shows when and how green marketing can reward. Green Marketing involves considering activities that are required to manufacture and aid the marketing of goods or services with producing least effect on surroundings and along with that fully satisfying customer's requirements and wishes. This concept works in all directions as by satisfying customer, obtaining high profits for firms and being friendly to environment (Sheikh, Shahzad, \& Ishak, 2016; Sugiyarti, 2015; Yanzheng, Zengxiang, \& Changhong, 2015). To use green marketing successfully companies should focus on green marketing instruments that include eco-friendly ads and eco-brand etc. These instruments increase understanding of customer towards green marketing and green products which leads to their intention to purchase. This concept has gained attention from past many years (Vătămănescu et al., 2017; Wang \& Kim, 2017; West et al., 2015; Yaacob et al., 2019). The reason of this increase attention is rapid commercial development, comfy way of living, bulk manufacturing, and overemphasize on promotion, a lot of competition and internationalization. Green marketing is shown helpful in profit generation; in studies its positive relation to customer attraction, their purchase intention, buying behaviors and satisfaction has been viewed. Nature of green marketing makes it very suitable for today's damaged environment.

\subsection{Marketing Innovation on pricing and marketing performance}

Setting prices innovatively increases attraction of the product which in turn enhances the marketing performance of the product. Innovative pricing can be a competitive advantage for a firm. The technique satisfies customer and increase profits as well. Companies are using value informed pricing, in this way companies set prices by keeping in view the buyer's awareness about the advantages of offered item and the way buyer deal these advantages against price. By doing this value is created in customer's mind and he believes that he is paying for something precious and valuable to have. This mechanism increase product's market performance as customers are satisfied with the 
JOURNAL OF SECURITY AND SUSTAINABILITY ISSUES

ISSN 2029-7017/ISSN 2029-7025 (online)

2020 Volume 9 May

http://doi.org/10.9770/jssi.2020.9.M(17)

pricing. It is also figured out that for marketing performance, price is of more concern in developing countries, because buyers from developing countries are more sensitive about product's price (Shaltoni, 2017; Sheikh, Rana, Inam, Shahzad, \& Awan, 2018). But for firms to offer innovative pricing there is a need to be more attentive towards market changes. This type of pricing can only be offered after keen observation, examining and sound analysis of market fluctuations. It is because customers are more aware in this era about what they are paying for the product and services (Reda, 2018; Rishi \& Bandyopadhyay, 2017; Sega, 2017; Shaltoni, 2017; Sheikh et al., 2018). Hence this study propose following hypothesis

H1: Marketing innovation on pricing has a significant impact on marketing performance.

\subsection{Marketing Innovation on packaging and marketing performance}

Previously companies use wrapping and packing of a product just to guard it but latter it is advanced as identification of a brand. Packaging is considered as 'quite salesman', because it not only influences the appearance of a product but attract customer to buy it. So, if a product is offered in innovate and unique packaging it leads to high performance of product in market. Scholars have witnessed it as an important factor in four Ps. Packaging is also an independent base of innovation for merchants, procedures and items (Bauer, Freundt, Gordon, Perrey, \& Spillecke, 2016; Beukes \& van Wyk, 2016; Herman, Setiyaningrum, \& Ferdinand, 2018). Companies are involved in better packaging innovations as it is a way of improvement and economic benefit as it leads to high profits with cheap costs. Innovative packaging can be used due to different reasons such as it act as invisible influencer on customer, it influence positively the efficiency of product and it enhance the eco-friendly image of product. It is studied that products with innovate packaging are positively linked with purchase decision of customer. Not only this but products that are packaged innovatively are more convenient to handle while delivering, loading, storage and shipping. Due to given arguments this paper offer following hypothesis

$\mathrm{H} 2$ : Marketing innovation on packaging has a significant impact on marketing performance.

\subsection{Marketing Innovation on promotion and marketing performance}

The current era is all about promotion, here well promoted products do more business than others because customers are more informed about them. internet has changed lifestyles of people, and in the form of mobile, laptop and other such electronic devices, it's influence on people's life has increased many folds as compare to past. So these days it is more profitable for firms to focus on online advertising. Firms now offer their goods, services and ideas through internet, they communicate directly with them through it and then they deliver their products to them without a middleman. Due to these circumstances online shopping is trending now. These internet promotion tactics are changing commercial atmosphere. These tactics are increasing the visibility and attainability of a product which in turn increasing the marketing performance of a product. Before going to promote the product and service online, firms must have a comprehensive research on buyer's views, philosophies, intentions and approaches about the product (West et al., 2015; Yaacob et al., 2019; Zekanović-Korona \& Grzunov, 2019). For this companies conducts online surveys, offer questionnaires and obtain data from various websites to improve the market performance of their product, service or idea. In response to given arguments this paper offer following hypothesis

H3: Marketing innovation on promotion has a significant impact on marketing performance.

\subsection{Mediating role of GPMA between marketing Innovation on pricing and marketing performance}

Agility here refers to long life of product. Small amount of writings are offered about GPMA. Studies shows that price is determinant of buying behavior, so if a product is priced innovatively it can lead to competitive advantage. Some firm uses value added pricing where they deal with customer's mind by comparing the benefits against price. Similarly another innovative pricing technique that is used by firms is green pricing. In this pricing strategy 
JOURNAL OF SECURITY AND SUSTAINABILITY ISSUES

ISSN 2029-7017/ISSN 2029-7025 (online)

2020 Volume 9 May

http://doi.org/10.9770/jssi.2020.9.M(17)

customers happily pay extra for the products that are eco-friendly. Usually the prices are high if the product is of better quality and eco-friendly, because the materials used in their manufacturing are expensive. During this pricing strategy buyer's concern and awareness about surroundings is examined. The more buyers are sensitive toward environment, more they will willingly pay extra. The cost of company to produce such products is also high so, because customers are more aware today, they favorably pay premium prices for such products (Aljanabi \& Noor, 2015; Arslanagic-Kalajdzic \& Zabkar, 2015; Atanassova \& Clark, 2015). Due to this awareness circulation and movement of product in market increases. Hence in response to these innovative pricing strategies e.g. value added pricing and green pricing, these products are liked by customers and in turn their market performance increase. Therefore this study propose following hypothesis

H4: GPMA will moderate the relationship between marketing innovation on pricing and marketing performance.

\subsection{Mediating role of GPMA between marketing Innovation on packaging and marketing performance}

Packaging is a significant feature of promotional mix. It is a source of novelty in a product. It also helps in reducing costs with increase in returns. Studies show that green packaging is most frequently requested by customers. Companies are using different packaging techniques and one of them is green packaging which is very much in nowadays. This type of packaging offer various benefits like, it is easily reutilize able, produce from ecological ingredients, returnable and reusable. Innovatively the packaging of product is reduced, which results in money saving before advertisement. In order to lessen the impact of packing on surroundings, companies uses various ways for example, ingredients intake to produce a product are reduced, packaging leftovers are reduced, and the advertisement of recyclable and biodegradable product packaging are increased. Such packaging attributes are must be observable. This way packaging of product become more beautiful and eye-catching (Benzo et al., 2017; Costanza, 2017; Dam et al., 2019). So customers feel attraction and charm in these products. This scenario increases the circulation and agility of these products in the market which increase its market performance. Consequently with the help of given arguments this study propose following hypothesis

H5: GPMA will moderate the relationship between marketing innovation on packaging and marketing performance.

\subsection{Mediating role of GPMA between marketing Innovation on promotion and marketing performance}

This is the age of promotion, and effectively promoted products and services produce high returns. Changing patterns of life require marketing strategies to change accordingly, and this era requires promotional strategies that involve internet, as it has become a part of life for almost every one. Products that are not promoted through internet are nowhere in completion. So, internet is an important platform for companies to promote. But the use of internet in promotion of product, service or message should be wise, which means that communication there should be up to the mark. It is very important to notify and update buyers. Studies show that customers are more responsive towards green promotion. So it is helpful for companies to produce ecological advertisement, as it is examined that customer like the promotion of green and biological products. Customers are also attracted towards TV ads and printed promotions of green products. Later these attractions become the cause of customer buying (Aljanabi \& Noor, 2015; Arslanagic-Kalajdzic \& Zabkar, 2015; Atanassova \& Clark, 2015). Studies also indicate that sound information and understanding should be provided in promotions about the working of products. If the information provided is inappropriate or incomplete it negatively effects buying decision. Green promotion should focus on ecological advantages of product, highlight green lifestyles, enhance eco-friendly image of company (Dikova, Van Witteloostuijn, \& Parker, 2017). These types of promotions increase agility of products in market, and this way the performance of product increase in market. These arguments help the study to offer following hypothesis.

H5: GPMA will moderate the relationship between marketing innovation on promotion and marketing performance (see Figure 2). 
JOURNAL OF SECURITY AND SUSTAINABILITY ISSUES

ISSN 2029-7017/ISSN 2029-7025 (online)

2020 Volume 9 May

http://doi.org/10.9770/jssi.2020.9.M(17)

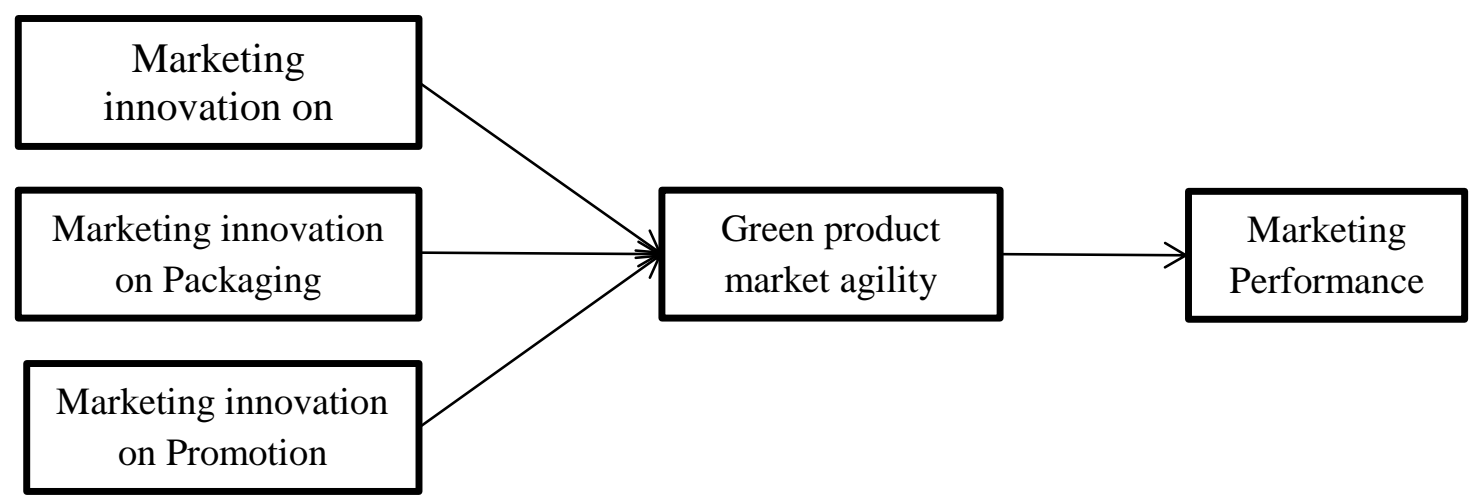

Figure 2: Research Framework

\section{Research Methodology}

\subsection{Population and Sampling}

In this researcher study, researcher desired to observed role of marketing innovation on pricing, packaging and promotion on marketing performance, in mediating role of green product market agility. Researcher has been accompanied apparel industry of Indonesia as population of study because this sector is greater contributor in economy of Indonesia and employment sources. As Indonesia desired to enhance revenue from textile sector that's why this sector has to innovate a lot for achieving competitive advantages over china and Vietnam which are producing cheap and innovative products. Due to these reasons, researcher consider it essential to proposed few parameters for increasing marketing performance. Sampling frame of this research study consist of Kana Goods, Hlaii, Seratus Kapas and Cinta Bumi, as all these companies have been considered as most sustainable garments brands but these companies desired to perform extra ordinally and increase word of mouth that's why researcher considered it beneficial to collect the data from managerial employees of marketing department of these four companies. Researcher uses purposive sampling technique for selecting specific respondents from only marketing department as this study is related to marketing performance and innovation. For data collection, researcher distributes 460 questionnaires between managerial employees but out of 460 only 335 responded. After performing data cleaning process, researcher attain only 309 valid responses.

\subsection{Data collection Procedure}

As this research study has never been conducted in previous literature that's why researcher has to collect primary data, for which researcher considers survey questionnaire most appropriate option. Questionnaire has been categorized into two type closed ended questions such as demographic and variable scale items, for collecting quantitative and objective responses. Moreover, questionnaire has been written originally in English language but for collecting data from Indonesian people researcher convert it into native language. As far as data collection procedure has been completed, researcher again translate it back into English language for data analysis process. Before finalizing questionnaire, researcher verify the understandability of items through pretest approach and checked content validity of measure by collecting feedback of industrial practitioner. Further, researcher administered finalized form of questionnaire through self-administering and online administering techniques, as it enables respondents to solved questionnaire appropriately and conveniently. 
JOURNAL OF SECURITY AND SUSTAINABILITY ISSUES

ISSN 2029-7017/ISSN 2029-7025 (online)

2020 Volume 9 May

http://doi.org/10.9770/jssi.2020.9.M(17)

\subsection{Measures}

Researcher takes into account much related research works of various authors in previous literature, for adapting measurement items which measured role of concerned variables of study. As researcher considered them more authentic and reliable that's why researcher considered them for measuring response of respondents regarding impact of proposed variables. Researcher measured green product market agility through 3 survey items adapted from (Laroche, Bergeron, \& Barbaro-Forleo, 2001), for marketing innovation on pricing measurement 3 survey items have been adapted from (Laroche et al., 2001) and for marketing innovation on promotion measurement, 5 survey items have been adapted from (Laroche et al., 2001). Further, researcher measured marketing innovation on packaging construct through 6 survey items taken from work of (Laroche et al., 2001) and for measuring marketing performance 9 measurement items have been taken from (Reid, 2005). 5-point Likert scale has been considered for measurement of all these survey items, in this scale 1 stands for strongly disagree and 5 stands for strongly agree (Thaker et al., 2020).

\subsection{Data Analysis}

Researcher accompanied SPSS for applying various tests such as researcher performed regression test, correlation test and descriptive statistics test for the analyses of collected data. SPSS has also been accompanied for running diagnosis of reliability, assessment of reliability based on two criteria such as (1) Composite reliability and (2) Cronbach's alpha. These two criteria must have the values in specified threshold range such as greater than 0.70 because it has been considered that above 0.70 cutoff value internal consistency and items reliability is ensured. As far as AMOS is concerned, researcher accompanied it for running two analysis approaches such as confirmatory factor analysis and structure equation modeling. SEM has been taken into consideration for assessing acceptance or rejection status of hypotheses and CFA has been accompanied for analyzing convergent validity, discriminant validity and model fitness.

\section{Results and Analysis}

Data for this study was collected from 309 different people from Indonesia among which 127 were males and 182 were females. Moreover, the educational qualifications and age factors are also very important factors that must be considered.

Table 1: Descriptive Statistics

\begin{tabular}{|c|c|c|c|c|c|c|c|}
\hline & $\mathrm{N}$ & Minimum & Maximum & Mean & SD & Skewness & \\
\hline & Statistic & Statistic & Statistic & Statistic & Statistic & Statistic & Std. Error \\
\hline MInnPrice & 309 & 1.00 & 5.00 & 3.5275 & 1.11547 & -.777 & .139 \\
\hline MInnPromo & 309 & 1.00 & 5.00 & 3.6091 & 1.11596 & -.865 & .139 \\
\hline MInnPack & 309 & 1.00 & 5.00 & 3.5507 & 1.08127 & -.840 & .139 \\
\hline GPMAgility & 309 & 1.00 & 6.33 & 3.3959 & 1.08597 & -.228 & .139 \\
\hline MarketPerf & 309 & 1.00 & 5.00 & 3.4398 & 1.11924 & -.573 & .139 \\
\hline Valid N (listwise) & 309 & & & & & & \\
\hline
\end{tabular}

The results of descriptive analysis have been given in the table 1 . These results evidently show that the data is normally distributed and there is no issue related to it. The data is skewed in the range of -1 to +1 which affirms the previous result. In addition, there is no outlier found in the data which can be confirmed as the value of minimum 
JOURNAL OF SECURITY AND SUSTAINABILITY ISSUES

ISSN 2029-7017/ISSN 2029-7025 (online)

2020 Volume 9 May

http://doi.org/10.9770/jssi.2020.9.M(17)

and maximum statistic values are in the range of 5 points Likert scale. Apart from them, standard deviation and mean have also been presented in the table 2 .

Table 2: KMO and Bartlett's Test

\begin{tabular}{lll}
\hline Kaiser-Meyer-Olkin Measure of Sampling Adequacy. & .929 \\
Bartlett's Test of Sphericity & Approx. Chi-Square & 9180.009 \\
& df & 325 \\
\hline
\end{tabular}

After studying about the descriptive analysis of the collected data, the next step is to determine whether the sample size of the data is adequate or normal. KMO and Bartlett's test are generally used for this purpose. The KMO test value in our case is 0.929 , which is effectively within the appropriate range i.e. 0.8 to 1 . This means that the sample size selected for this study is accurate and adequate, which can also be confirmed as the value of Bartlett's test is also within the range.

Table 3: Rotated Component Matrix

\begin{tabular}{|c|c|c|c|c|c|}
\hline & \multicolumn{5}{|c|}{ Component } \\
\hline & 1 & 2 & 3 & 4 & 5 \\
\hline PRI1 & & & & .743 & \\
\hline PRI2 & & & & .784 & \\
\hline PRI3 & & & & .826 & \\
\hline PRO1 & & & .819 & & \\
\hline PRO2 & & & .851 & & \\
\hline PRO3 & & & .859 & & \\
\hline PRO4 & & & .864 & & \\
\hline PRO5 & & & .852 & & \\
\hline PAC1 & & .781 & & & \\
\hline PAC2 & & .825 & & & \\
\hline PAC3 & & .805 & & & \\
\hline PAC4 & & .850 & & & \\
\hline PAC5 & & .803 & & & \\
\hline PAC6 & & .860 & & & \\
\hline GMA1 & & & & & .716 \\
\hline GMA2 & & & & & .753 \\
\hline GMA3 & & & & & .778 \\
\hline MP1 & .842 & & & & \\
\hline MP2 & .865 & & & & \\
\hline MP3 & .872 & & & & \\
\hline MP4 & .877 & & & & \\
\hline MP5 & .878 & & & & \\
\hline MP6 & .888 & & & & \\
\hline
\end{tabular}


JOURNAL OF SECURITY AND SUSTAINABILITY ISSUES

ISSN 2029-7017/ISSN 2029-7025 (online)

2020 Volume 9 May

http://doi.org/10.9770/jssi.2020.9.M(17)

$\begin{array}{ll}\text { MP7 } & .858 \\ \text { MP8 } & .830 \\ \text { MP9 } & .816\end{array}$

The table 3 shows the factor loading values of all the items that are included in the variables transforming of the study. The threshold value for all the items is greater than 0.7 , and in out study all the values are also greater than 0.7 which affirms that the variables of this study are not facing cross loading problem and they are no overlapped either. As all the results are satisfactory, we can move forward in the hypotheses testing process.

\begin{tabular}{llllllllll}
\multicolumn{8}{c}{ Table 4: Convergent and Discriminant Validity } \\
\hline & CR & AVE & MSV & MaxR(H) & PRI & PRO & PAC & GMA & MP \\
\hline PRI & 0.900 & 0.751 & 0.367 & 0.914 & $\mathbf{0 . 8 6 7}$ & & & & \\
PRO & 0.952 & 0.799 & 0.367 & 0.968 & 0.606 & $\mathbf{0 . 8 9 4}$ & & & \\
PAC & 0.949 & 0.759 & 0.338 & 0.982 & 0.562 & 0.581 & $\mathbf{0 . 8 7 1}$ & & \\
GMA & 0.864 & 0.679 & 0.493 & 0.983 & 0.557 & 0.373 & 0.487 & $\mathbf{0 . 8 2 4}$ & \\
MP & 0.911 & 0.787 & 0.493 & 0.990 & 0.511 & 0.375 & 0.469 & 0.402 & $\mathbf{0 . 8 8 7}$ \\
\hline
\end{tabular}

The results of convergent and discriminant validity have been presented in the table 4 . It can be seen that the values of composite reliability are greater than 0.7 while the values of average variance extracts are greater than 0.5 . Both these values indicate the satisfactory results of the convergent validity. The discriminant validity also has satisfactory results according to the table as the variables are very close to each other instead of the other variables.

Table 5: Confirmatory Factors Analysis

\begin{tabular}{lll}
\hline Indicators & Threshold range & Current values \\
\hline CMIN/DF & Less or equal 3 & 2.753 \\
GFI & Equal or greater .80 & .845 \\
CFI & Equal or greater .90 & .945 \\
IFI & Equal or greater .90 & .945 \\
RMSEA & Less or equal .08 & .075 \\
\hline
\end{tabular}

The results of model fitness test have been presneted in table 5. This test is very imporant before moving further in the analysis process. In the table, the threshold values of each indicator have been given and the actual values are also evident at the same time. As all the values are satisfied according to the results, the model is considered to be fit (see figure 3 and figure 4 ). 
JOURNAL OF SECURITY AND SUSTAINABILITY ISSUES

ISSN 2029-7017/ISSN 2029-7025 (online)

2020 Volume 9 May

http://doi.org/10.9770/jssi.2020.9.M(17)

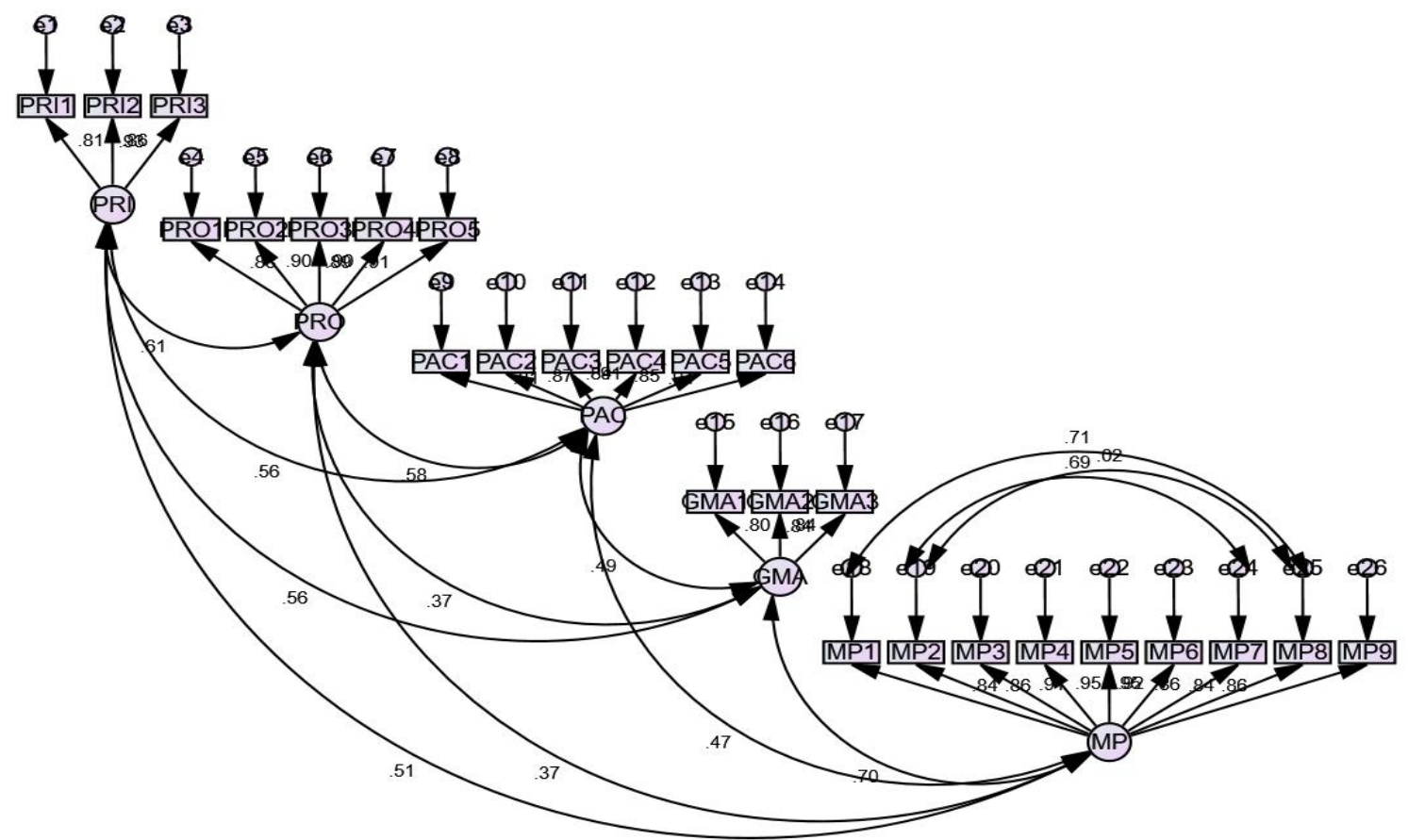

Figure 3: CFA

Table 6: Structural Equation Modeling

\begin{tabular}{lllll}
\hline Total Effect & MInnPack & MInnPromo & MInnPrice & GPMAgility \\
\hline GPMAgility & $.212^{* *}$ & $.235^{* *}$ & $.240^{* *}$ & .000 \\
MarketPerf & $.221^{* *}$ & $.354^{* * *}$ & .139 & $.467 * * *$ \\
Direct Effect & MInnPack & MInnPromo & MInnPrice & GPMAgility \\
GPMAgility & $.212^{* *}$ & $.235^{* *}$ & $.240^{* *}$ & .000 \\
MarketPerf & $.122^{*}$ & $.244^{* *}$ & .027 & $.467 * *$ \\
Indirect Effect & MInnPack & MInnPromo & MInnPrice & GPMAgility \\
GPMAgility & .000 & .000 & .000 & .000 \\
MarketPerf & $.099^{* *}$ & $.110^{* *}$ & $.112^{* *}$ & .000 \\
\hline
\end{tabular}

The results of SEM have been given in the table 6. In the direct effect portion, the impact of marketing innovation on packing and promotion on marketing performance is significant but the impact of marketing innovation on pricing is found as insignificant. The mediating impact of green product market agility has also been found as significant according to the results by 46.7 percent. 
JOURNAL OF SECURITY AND SUSTAINABILITY ISSUES

ISSN 2029-7017/ISSN 2029-7025 (online)

2020 Volume 9 May

http://doi.org/10.9770/jssi.2020.9.M(17)

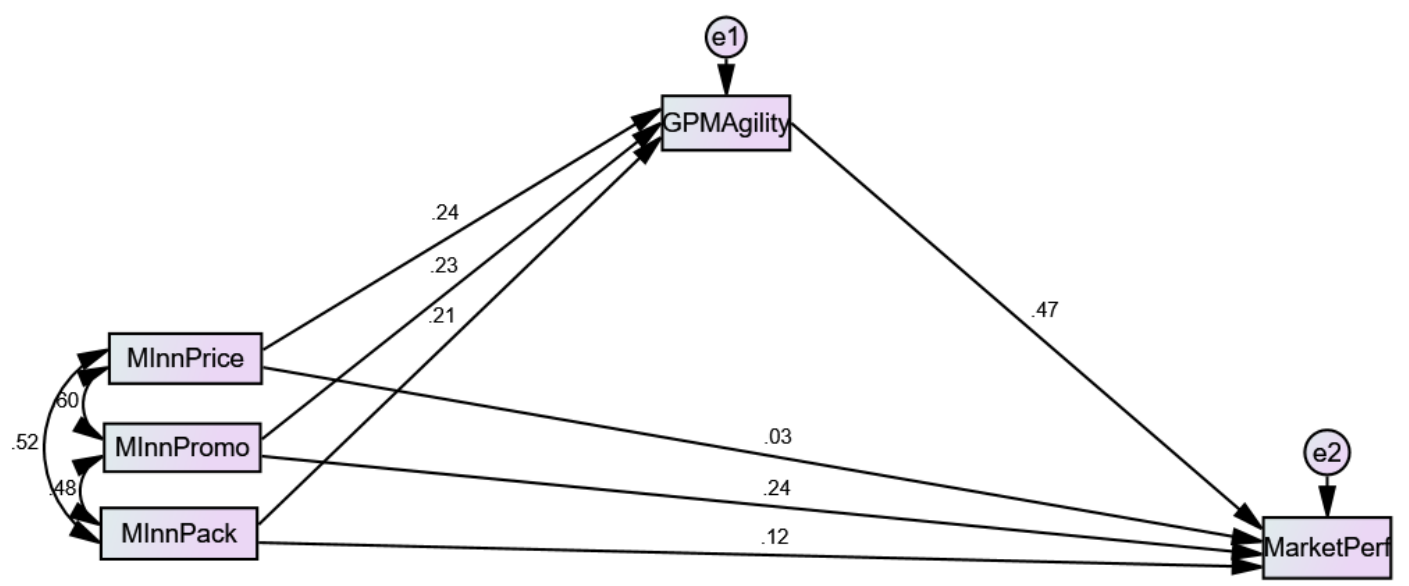

Figure 4: SEM

\section{Discussion and Conclusion}

\subsection{Discussion}

The following study illustrates the impact of marketing innovation dimensions on the marketing performance of the companies with the help of green product agility as a mediating variable. The following discussion section illustrates the results and findings. The results table and values indicate that the marketing innovation on pricing directly and significantly affects the marketing performance of the apparel industry in Indonesia. Research indicates and illustrates that the marketing innovation in pricing is the application of a new variable price calculation based exclusively on-demand factors for a particular product or service ( $\mathrm{Du}, \mathrm{Xu}$, Chen, \& Tsai, 2018). Moreover, the innovation process in presenting new financial products has become an antecedent condition to enhance the growth of financial institutions (Kapetaniou, Samdanis, \& Lee, 2018).

Moreover, the results also indicate that the marketing innovation on promotion has also a significant impact on marketing performance. Now, a day the companies mainly focus on promoting innovation and activities in order to increase financial performance. Sales promotion is seen as temporary incentives to encourage the trial or use of a product or service (Gonca \& Düzgün, 2018). The study also demonstrates that promotion strategies help to attract customers and buyers. At the same time, it helps to make a positive relationship with customers. Therefore, the marketing innovation on promotion has a significant relationship with marketing performance. While, on the other hand, the marketing innovation on the packaging has an insignificant relationship with marketing performance, according to the results and findings. The packaging and labels can be used by marketers to encourage potential buyers to purchase the product (Sen, Rajagopal, \& Bhattacharjee, 2019). However, in this case, the packaging has an insignificant impact on the marketing performance of the companies.

Furthermore, the role of green product agility has a mediating variable in relationship with marketing performance and marketing dimensions. The results show that the green product agility has a mediating variable in relationship with marketing innovation on price and marketing performance. A study illustrates that green marketing helps to process of selling products and/or services based on their environmental benefits (Sadiku, Kotteti, \& Musa, 2018). The green product agility has also a positive mediating role in the relationship with marketing innovation on promotion with marketing performance. It is an obvious assumption that green marketing is the potential consumers will view a product or service's "greenness" as a benefit and base their buying decision accordingly. While, on the other hand, the green market product agility has an insignificant impact on the relationship with marketing 
JOURNAL OF SECURITY AND SUSTAINABILITY ISSUES

ISSN 2029-7017/ISSN 2029-7025 (online)

2020 Volume 9 May

http://doi.org/10.9770/jssi.2020.9.M(17)

innovation on packaging on marketing performance. The role of green product sustainability does not really enhance the relationship between packaging and marketing performance.

\subsection{Implications}

The results and discussion shows that 4 ps such as product innovation, price, and promotion significantly affect the financial performance of the apparel industry positively. These factors can be controlled by a business to a certain extent. When "mixed" or blended strategically, they can produce desired behaviors from your target audiences. These elements have enhanced the financial performance of the companies and create positive results.

\subsection{Limitation/Recommendation}

The study does not really focus on all 4Ps as a marketing mix. Product, price, and promotion have been analyzed while the 'place' factor does not analyze. Therefore, it is recommended that future studies must focus on place factors as a marketing mix. Moreover, the sample size in a given study is too small which is a limitation of the research. The future study must try to fill this gap.

\section{Conclusion}

The study mainly highlights the importance of marketing communication dimensions on the performance of the companies in the apparel industry of Indonesia. The sample population of the study is 309, while 127 are male and 182 are female. The results and discussion section illustrate that pricing and promotion innovation has a direct and significant impact on marketing performance while the innovation in packaging has a negative or insignificant impact on marketing performance. While at the same time the green product market agility has a significant mediating role with all marketing dimension variables.

\section{References}

Aljanabi, A. Q. R. A., \& Noor, N. A. M. (2015). Critical determinants of technological innovation: a conceptual framework and a case study from Iraq. International Business Research, 8(2), 16-27. http://dx.doi.org/10.5539/ibr.v8n2p16

Arslanagic-Kalajdzic, M., \& Zabkar, V. (2015). The external effect of marketing accountability in business relationships: Exploring the role of customer perceived value. Industrial marketing management, 46, 83-97. https://doi.org/10.1016/j.indmarman.2015.03.002

Atanassova, I., \& Clark, L. (2015). Social media practices in SME marketing activities: A theoretical framework and research agenda. Journal of customer behaviour, 14(2), 163-183. https://doi.org/10.1362/147539215X14373846805824

Bauer, T., Freundt, T., Gordon, J., Perrey, J., \& Spillecke, D. (2016). Marketing Performance: How Marketers Drive Profitable Growth: John Wiley \& Sons.

Benzo, R., Mohsen, M. G., \& Fourali, C. (2017). Marketing research: planning, process, practice: Sage.

Beukes, C., \& van Wyk, G. (2016). An investigation of the marketing performance measurement practices in Hatfield Volkswagen group. African Journal of Business Management, 10(6), 131-139. https://doi.org/10.5897/AJBM2015.7772

Costanza, F. (2017). Social media marketing and value co-creation: a dynamic performance management perspective. Paper presented at International Conference on Exploring Services Science (pp.131-143). Springer. https://doi.org/10.1007/978-3-319-56925-3_11

Dam, N. A. K., Le Dinh, T., \& Menvielle, W. (2019). A systematic literature review of big data adoption in internationalization. Journal of Marketing Analytics, 7(3), 182-195. https://doi.org/10.1057/s41270-019-00054-7 
JOURNAL OF SECURITY AND SUSTAINABILITY ISSUES

ISSN 2029-7017/ISSN 2029-7025 (online)

2020 Volume 9 May

http://doi.org/10.9770/jssi.2020.9.M(17)

Dewnarain, S., Ramkissoon, H., \& Mavondo, F. (2019). Social customer relationship management in the hospitality industry. Journal of Hospitality, 1(1), 1-14.

Di Fatta, D., Caputo, F., \& Dominici, G. (2018). A relational view of start-up firms inside an incubator: the case of the ARCA consortium. European Journal of Innovation Management, 21(4), 601-619. https://doi.org/10.1108/EJIM-08-2017-0110

Dikova, D., Van Witteloostuijn, A., \& Parker, S. (2017). Capability, environment and internationalization fit, and financial and marketing performance of MNEs' foreign subsidiaries: An abductive contingency approach. Cross Cultural \& Strategic Management, 24(3), 405-435. https://doi.org/10.1108/CCSM-01-2016-0003

Du, P., Xu, L., Chen, Q., \& Tsai, S.-B. (2018). Pricing competition on innovative product between innovator and entrant imitator facing strategic customers. International Journal of Production Research, 56(5), 1806-1824. https://doi.org/10.1080/00207543.2015.1134837

Gonca, T. Y., \& Düzgün, F. (2018). Performance of Sales Person in a Smartphone Market in Turkey. Financial and credit activity: problems of theory and practice, 3(26), 143-150. https://doi.org/10.18371/fcaptp.v3i26.144792

Haseeb, M., Haouas, I., Nasih, M., Mihardjo, L. W., \& Jermsittiparsert, K. (2020). Asymmetric impact of textile and clothing manufacturing on carbon-dioxide emissions: Evidence from top Asian economies. Energy, 196, 117094. https://doi.org/10.1016/j.energy.2020.117094

Hailegiorgis, D. S., \& Hagos, F. (2016). Structure and performance of vegetable marketing in East Shoa zone, Oromia Region, Ethiopia. Journal of Marketing and Consumer Research, 26, 7-16.

Hendrayati, H., \& Gaffar, V. (2016). Innovation and Marketing Performance of Womenpreneur in Fashion Industry in Indonesia. ProcediaSocial and Behavioral Sciences, 219, 299-306. https://doi.org/10.1016/j.sbspro.2016.04.034

Herman, L. E., Setiyaningrum, A., \& Ferdinand, A. T. (2018). Techno-Entrepreneurial Relationship Marketing to ignite the SMEs Marketing Performance in Indonesia. Calitatea, 19(167), 98-106.

Kapetaniou, C., Samdanis, M., \& Lee, S. H. (2018). Innovation policies of Cyprus during the global economic crisis: Aligning financial institutions with National Innovation System. Technological Forecasting and Social Change, 133, 29-40. https://doi.org/10.1016/j.techfore.2018.02.019

Khalid, N., Ahmed, U., Tundikbayeva, B., \& Ahmed, M. (2019). Entrepreneurship and organizational performance: Empirical insight into the role of entrepreneurial training, culture and government funding across higher education institutions in Pakistan. Management Science Letters, 9(5), 755-770. http://dx.doi.org/10.5267/j.msl.2019.1.013

Lim, R. (2016). Becoming Consumer Entrepreneurs: A Grounded Theory of Consumer Entrepreneurship. Doctoral dissertation, Swimburne University of Techology.

Nadda, V., Dadwal, S., \& Rahimi, R. (2017). Promotional Strategies and New Service Opportunities in Emerging Economies: IGI Global.

Nguyen, B., Melewar, T., \& Schultz, D. E. (2017). Asia branding: Connecting brands, consumers and companies: Palgrave MacMillan.

Reda, Y. (2018). E-marketing for Tourism Business Development in Ethiopia: Its Practice, Challenges and Implications on Performance of Tour Operating Firms. Doctotal dissertation, Addis Ababa University.

Rishi, B., \& Bandyopadhyay, S. (2017). Contemporary Issues in Social Media Marketing: Routledge.

Sadiku, M. N., Kotteti, C. M., \& Musa, S. M. (2018). Green Marketing: A Primer. International Journal of Advances in Scientific Research and Engineering, 4(11), 17-20. http://doi.org/10.31695/IJASRE.2018.32932

Sega, N. J. (2017). Beyond The OVOP Through Design Thinking Approach. Doctoral Dissertation, Ritsumeikan Asia Pacific University.

Sen, S., Rajagopal, K., \& Bhattacharjee, K. (2019). Marketing of Greener Products: Trends and Practices. In Handbook of Research on Economic and Political Implications of Green Trading and Energy Use (pp. 293-314): IGI Global. 
JOURNAL OF SECURITY AND SUSTAINABILITY ISSUES

ISSN 2029-7017/ISSN 2029-7025 (online)

2020 Volume 9 May

http://doi.org/10.9770/jssi.2020.9.M(17)

Shaltoni, A. M. (2017). From websites to social media: exploring the adoption of internet marketing in emerging industrial markets. Journal of Business \& Industrial Marketing, 32(7), 1009-1019. http://dx.doi.org/10.1108/JBIM-06-2016-0122

Sheikh, A. A., Rana, N. A., Inam, A., Shahzad, A., \& Awan, H. M. (2018). Is e-marketing a source of sustainable business performance? Predicting the role of top management support with various interaction factors. Cogent Business \& Management, 5(1), 1516487. https://doi.org/10.1080/23311975.2018.1516487

Sheikh, A. A., Shahzad, A., \& Ishak, A. B. K. (2016). The mediating impact of e-marketing adoption on export performance of firms: A conceptual study. Journal of Technology and Operations Management, 11(1), 48-58.

Sugiyarti, G. (2015). Creation marketing capabilities as antecedents for success marketing performance. Journal of Research in Marketing, 5(1), 321-329.

Thaker, H. M. T., Sakaran, K., Nanairan, N., Thaker, M. M. T. and Hussain, H. I. (2020), Drivers of loyalty among non-Muslims towards Islamic banking in Malaysia: Evidence from SmartPLS, International Journal of Islamic and Middle Eastern Finance and Management, https://doi.org/10.1108/IMEFM-07-2018-0211

Vătămănescu, E.-M., Gazzola, P., Dincă, V., \& Pezzetti, R. (2017). Mapping entrepreneurs' orientation towards sustainability in interaction versus network marketing practices. Sustainability, 9(9), 1580. https://doi.org/10.3390/su9091580

Wang, Z., \& Kim, H. G. (2017). Can social media marketing improve customer relationship capabilities and firm performance? Dynamic capability perspective. Journal of Interactive Marketing, 39, 15-26. https://doi.org/10.1016/j.intmar.2017.02.004

West, D. C., Ford, J., \& Ibrahim, E. (2015). Strategic marketing: creating competitive advantage: Oxford University Press, US A.

Yaacob, R., Baroto, M. B., Kamarudin, S., \& Arifin, N. (2019). Moderation Effect of Top Management Support on the Relationship between Customer Reference Marketing and Market Performance. International Journal of Academic Research in Business and Social Sciences, 9(7), 1263-1297. http://dx.doi.org/10.6007/IJARBSS/v9-i7/6263

Yanzheng, T., Zengxiang, C., \& Changhong, B. (2015). Destination Marketing Performance: Current State and Value Chain Model. Tourism Tribune/Lvyou Xuekan, 30(1).

Zekanović-Korona, L., \& Grzunov, J. (2019). THE IMPLICATIONS OF ICT USE IN TOURISTS' TRAVEL PATTERNS: CASE OF ZADAR. Paper presented at the 12th Annual Conference of the EuroMed Academy of Business. 
JOURNAL OF SECURITY AND SUSTAINABILITY ISSUES

ISSN 2029-7017/ISSN 2029-7025 (online)

2020 Volume 9 May

http://doi.org/10.9770/jssi.2020.9.M(17)

Muhartini SALIM

Faculty of Economics and Business, Universitas Bengkulu, Indonesia.

ORCID ID: https://orcid.org/0000-0001-6372-1567

\section{Lizar Alfansi}

Faculty of Economics and Business, Universitas Bengkulu, Indonesia.

ORCID ID: https://orcid.org/0000-0002-8047-7129

\section{Muhammad Rahman FEBLIANSA}

Faculty of Economics, University of Dehasen, Bengkulu, Indonesia.

ORCID ID: $\underline{\text { https://orcid.org/0000-0001-5477-4552 }}$

\section{Marlina WIDIYANTI}

Faculty of Economics, Universitas Sriwijaya, Palembang, Indonesia

ORCID ID: $\underline{\text { https://orcid.org/0000-0003-0431-814x }}$

Marlina WIDIYANTi is Associate Professor of Financial Management and Strategic Management at Departement of Management in Economic Faculty, University of Sriwijaya.

ORCID ID: https://orcid.org/0000-0002-9667-3730

Register for an ORCID ID:

https://orcid.org/register

This work is licensed under the Creative Commons Attribution International License (CC BY).

http://creativecommons.org/licenses/by/4.0/

(c) (i) Open Access 